\title{
Improvement yield and nitrogen uptake of wheat through application of organic and inorganic fertilizers
}

\author{
MR Islam ${ }^{1 *}$, S Siraj ${ }^{1}$, A Huda ${ }^{1,2}$, MLN Begum ${ }^{3}$, S Bilkis ${ }^{1}$ \\ ${ }^{1}$ Department of Soil Science, Bangladesh Agricultural University, Mymensingh-2202, Bangladesh \\ ${ }^{1,2}$ Department of Soil Science, Sylhet Agricultural University, Sylhet-3100, Bangladesh \\ ${ }^{3}$ Practical Skill Development Training Department, Proshika, Mirpur-2, Dhaka-1216, Bangladesh
}

\begin{abstract}
An experiment was conducted at the Soil Science Field Laboratory of Bangladesh Agricultural University, Mymensingh during winter (Rabi) season of 2013-14 to evaluate the effect of integrated use of organic and inorganic fertilizers on the growth, yield and nitrogen $(\mathrm{N})$ uptake of wheat. There were six treatments such as $\mathrm{T}_{0}$ (control), $\mathrm{T}_{1}$ [STB-CF (HYG)], $\mathrm{T}_{2}$ [STB-CF (HYG) + CD (5 t/ha)], $\mathrm{T}_{3}$ [STB-CF (HYG) +PM (3 t/ha)], $\mathrm{T}_{4}$ [STB-CF (HYG) COM (5 t/ha)] and $\mathrm{T}_{5}$ [FP (Farmers' practice)]. The experiment was laid out in a Randomized Complete Block Design with four replications. Soil test based nitrogen, phosphorus, potassium, sulphur, zinc and boron were used @ 100,20,60,10,3 and $2 \mathrm{~kg} \mathrm{ha}^{-1}$, respectively. The integrated use of organic and inorganic fertilizers significantly increased the yield attributes as well as grain and straw yields of wheat. The treatment $\mathrm{T}_{3}$ [STB-CF (HYG) + PM $\left(3\right.$ tha $\left.\left.^{-1}\right)\right]$ produced the highest grain yield of $3554 \mathrm{~kg} \mathrm{ha}^{-1}$ ( $69.67 \%$ increase over control) and straw yield of $3635 \mathrm{~kg} \mathrm{ha}^{-1}$ ( $62.83 \%$ increase over control). The lowest grain yield $\left(2094 \mathrm{~kg} \mathrm{ha}^{-1}\right)$ and straw yield $\left(2232 \mathrm{~kg} \mathrm{ha}^{-1}\right)$ were found in control treatment. The $\mathrm{N}$ content and uptake by wheat were also markedly influenced by combined use of organic and inorganic fertilizers and the treatment $\mathrm{T}_{3}$ demonstrated superior performance to other treatments. So, the applications of fertilizers in combination with poultry manure @ $3 \mathrm{t} \mathrm{ha}^{-1}$ can be used for the successful cultivation of wheat in Old Brahmaputra Floodplain soil.
\end{abstract}

Key words: Cowdung, poultry manure, compost, wheat yield, nitrogen uptake

Progressive Agriculturists. All rights reserve

*Corresponding Author: rafiqss69@bau.edu.bd

\section{Introduction}

Wheat (Triticum spp) is the most important cereal crop and ranks first both in acreage and production of the world (BBS, 2011). It has been established as the second most important staple food crop after rice in Bangladesh (Indira 2006). It is cultivated in different agro-ecological regions of the country. The production of wheat per unit area in Bangladesh is very low in comparison to that of agriculturally developed countries of the world due to paucity of agricultural inputs (Razzaque et al., 1992). Bangladesh produces $14,53,000$ metric tons of wheat per annum from 16,86,000 acres of land (BBS, 2011).It provides grains rich in food values containing $14.7 \%$ protein, $78.1 \%$ starch and $2.1 \%$ mineral matters (Peterson, 1965). Bangladesh is a small country with large population and its population is increasing day by day. So, the cereal crop like wheat should be increased to meet the demand of the escalating population.

The beneficial role of animal manure in crop production has long been recognized. The utilization of cattle manure as a soil amendment is an integral part of the tropical countries farmers. However, the information that is lacking to most of the farmers is the methods of manure management practices for optimal quality before field application and time of 
application of animal manure for optimum crop production.

The use of inorganic chemical fertilizers is essential for crop nutrition in order to maximize productivity. The crop yields especially of wheat are stagnant for the last couple of years. The use of organic manures and composted organic materials along with chemical fertilizers may be effective for further increase in crop yield. The present investigation was, therefore, undertaken to study the effect of organic and inorganic fertilizers in IPNS (Integrated Plant Nutrient Management System) system on the growth, yield and nitrogen uptake of wheat.

\section{Materials and Methods}

The experiment was conducted at the Soil Science Field Laboratory of Bangladesh Agricultural University, Mymensingh during the winter (Rabi) season of 2013-14. The soil of the experimental field belongs to Sonatala Series. The experimental soil was silt loam in texture having $\mathrm{pH}$ 6.94 , organic matter $1.62 \%$, total nitrogen $0.067 \%$, available phosphorus $10.45 \mathrm{mg} / \mathrm{kg}$, exchangeable $\mathrm{K}$ $0.08 \mathrm{me} / 100 \mathrm{~g}$ soil, available sulphur $12.00 \mathrm{mg} / \mathrm{kg}$ and cation exchange capacity $15.0 \mathrm{me} / 100 \mathrm{~g}$ soil. The recommended high yielding wheat variety Kanchan was used as the test crop in this experiment. The experiment was laid out in a Randomized Complete Block Design (RCBD) with six treatments and four replications. The total numbers of plots were 24 . The unit plot size was $5 \mathrm{~m}$ x $4 \mathrm{~m}$ having spacing between plot to plot $0.5 \mathrm{~m}$ and block to block $1 \mathrm{~m}$. There were six treatments; $\mathrm{T}_{0}$ (Control), $\mathrm{T}_{1}$ [STB-CF (HYG)], $\mathrm{T}_{2}$ [STB-CF (HYG) $+\mathrm{CD}(5 \mathrm{t} / \mathrm{ha})]$ on IPNS basis, $\mathrm{T}_{3}[\mathrm{STB}-\mathrm{CF}(\mathrm{HYG})+$ PM (3 t/ha)] on IPNS basis, $\mathrm{T}_{4}$ [STB-CF (HYG) + COM (5 t/ha)] on IPNS basis, $\mathrm{T}_{5}$ [FP (Farmers practice)]. Here, $[\mathrm{STB}=$ Soil Test Basis, $\mathrm{CF}=$ Chemical fertilizer, $\mathrm{CD}=\mathrm{Cow}$ dung, $\mathrm{PM}=$ Poultry manure, $\mathrm{COM}=$ Compost, $\mathrm{FP}=$ Farmers' practice, $\mathrm{HYG}=$ High yield goal].

Well decomposed cow dung, compost and poultry manure were applied to the plots as per the treatments by mixing with the soil well before 7 days of sowing. The nutrient content in cow dung, poultry manure and compost has been depicted in Table 1 .
The amount of nitrogen, phosphorus, potassium, sulphur and boron required for each plot was calculated and used as per requirement. One third of urea and the full amount of TSP, MOP, gypsum and boric acid were applied one day before transplanting. The rest of urea was applied in two equal splits; one at maximum tillering stage (30 days after sowing) and the other at spike initiation stage (60 days after sowing). Seeds of wheat were sown@150 kg ha ${ }^{-1}$ in lines and covered by soil with hand. The line to line distance was $20 \mathrm{~cm}$ and the depth of furrow was about $6 \mathrm{~cm}$. A strip of wheat crop was established as border crops. Intercultural operations were done for ensuring and maintaining the normal growth of the crop. The crop was harvested at full maturity. Grain yield was recorded on $14 \%$ moisture basis and straw yield on sun dry basis. Five hills were randomly selected from each plot at maturity to record the growth and yield contributing characters. Grain and straw samples were analyzed for $\mathrm{N}$ content following the method outlined by Bremner and Mulvaney (1982). The $\mathrm{N}$ uptake by grain and straw was calculated from its content and yield data using the equation, Nitrogen uptake $=[$ Nitrogen content (\%) $\mathrm{x}$ Yield $\left.\left(\mathrm{kg} \mathrm{ha}{ }^{-1}\right)\right] / 100$. All the data were statistically analyzed by F-test and the mean differences were ranked by DMRT at 5\% level (Gomez and Gomez, 1984).

Table 1. Nutrient content in cow dung, poultry manure and compost

\begin{tabular}{|l|c|c|c|c|}
\hline \multirow{2}{*}{$\begin{array}{c}\text { Name of } \\
\text { manure }\end{array}$} & \multicolumn{4}{|c|}{ Nutrient contents (\%) } \\
\cline { 2 - 5 } & $\mathbf{N}$ & $\mathbf{P}$ & $\mathbf{K}$ & $\mathbf{S}$ \\
\hline Cow dung & 0.57 & 0.7 & 0.69 & 0.23 \\
\hline $\begin{array}{l}\text { Poultry } \\
\text { manure }\end{array}$ & 1.8 & 1.13 & 0.81 & 0.35 \\
\hline Compost & 2.9 & 0.05 & 1.55 & 0.165 \\
\hline
\end{tabular}

Source: Islam et al. (2014)

\section{Results and Discussion}

\section{Growth and yield contributing characters}

Growth and yield contributing characters such as plant height, effective tillers hill ${ }^{-1}$, spike length and spikelets spike ${ }^{-1}$ were influenced significantly due to application of organic and inorganic fertilizer in different combinations (Table 2). The tallest plant of $73.75 \mathrm{~cm}$ was observed in the treatment $T_{1}$ with the 
application of chemical fertilizers at recommended dose and it was identical with $\mathrm{T}_{2}$ [STB-CF (HYG) $+\mathrm{CD}(5 \mathrm{t} / \mathrm{ha})$ ], $\mathrm{T}_{3}$ [STB-CF (HYG) +PM (3 t/ha)], $\mathrm{T}_{4}$ [STB-CF (HYG) COM ((5 t/ha)] and $\mathrm{T}_{5}$ [FP (Farmers' practice)]. The shortest plant of $57.40 \mathrm{~cm}$ was recorded in the control (To) treatment. The highest number of effective tillers hill ${ }^{-1}$ of 7.67 was found in both $\mathrm{T}_{3}$ [STB-CF (HYG) $\left.+\mathrm{PM}(3 \mathrm{t} / \mathrm{ha})\right]$ and $\mathrm{T}_{5}$ [FP (Farmers' practice)] treatments and they were identical. The lowest number of effective tillers hill ${ }^{-1}$ was observed in control treatment. The treatments $\mathrm{T}_{1}, \mathrm{~T}_{2}$ and $\mathrm{T}_{4}$ showed statistically similar effective tillers hill ${ }^{-1}$. The highest spike length $(12.07 \mathrm{~cm})$ was found in $\mathrm{T}_{1}$ [STB-CF (HYG)] with the application of chemical fertilizers. The treatments $\mathrm{T}_{2}, \mathrm{~T}_{3}, \mathrm{~T}_{4}$, and $\mathrm{T}_{5}$ showed statistically similar spike length of wheat with the values of $11.90,11.83$, 11.37 and $11.07 \mathrm{~cm}$, respectively. The lowest value of $7.77 \mathrm{~cm}$ was obtained in control. The number of total grains spike- due to different treatments ranged from 65.00 to 83.00 and the maximum number was observed in $\mathrm{T}_{3}$ [STB-CF $(\mathrm{HYG})+\mathrm{PM}$ (3 t/ha)]. The lowest number of grains spike ${ }^{-1}$ (65.00) was found in control. The 1000-grain weight did not show any significant variation due to the application of manures and fertilizer in different combinations. Many researchers reported that combined application of manures and fertilizers increased the plant height and tillers hill ${ }^{-1}$ (Khan et al., 2007), spike length, (Singh et al., 2001) and filled grains spike $^{-1}$ (Satyannarayana et al., 2002).

Table 2. Effects of manures and fertilizers on the growth and yield components of wheat

\begin{tabular}{|l|c|c|c|c|c|}
\hline Treatments & $\begin{array}{c}\text { Plant height } \\
(\mathbf{c m})\end{array}$ & $\begin{array}{c}\text { Tillers hill } \\
(\mathbf{N o})\end{array}$ & $\begin{array}{c}\text { Spike } \\
\text { length }(\mathbf{c m})\end{array}$ & $\begin{array}{c}\text { Spikelets } \\
\text { spike }^{-1} \\
(\mathbf{N o .})\end{array}$ & $\begin{array}{c}\text { 1000-grain } \\
\text { weight } \\
\text { (g) }\end{array}$ \\
\hline $\mathrm{T}_{0}$ [control] & $57.40 \mathrm{~b}$ & $3.67 \mathrm{~b}$ & $7.77 \mathrm{~b}$ & $65.00 \mathrm{~b}$ & 37.87 \\
\hline $\mathrm{T}_{1}[\mathrm{STB}-\mathrm{CF}(\mathrm{HYG})]$ & $73.75 \mathrm{a}$ & $7.00 \mathrm{a}$ & $12.07 \mathrm{a}$ & $81.67 \mathrm{a}$ & 42.90 \\
\hline $\mathrm{T}_{2}[\mathrm{STB}-\mathrm{CF}(\mathrm{HYG})+\mathrm{CD}]$ & $70.84 \mathrm{a}$ & $7.00 \mathrm{a}$ & $11.90 \mathrm{a}$ & $78.00 \mathrm{a}$ & 41.30 \\
\hline $\mathrm{T}_{3}[\mathrm{STB}-\mathrm{CF}(\mathrm{HYG})+\mathrm{PM}]$ & $73.03 \mathrm{a}$ & $7.67 \mathrm{a}$ & $11.83 \mathrm{a}$ & $83.00 \mathrm{a}$ & 44.97 \\
\hline $\mathrm{T}_{4}[\mathrm{STB}-\mathrm{CF}(\mathrm{HYG}) \mathrm{COM}]$ & $72.47 \mathrm{a}$ & $6.00 \mathrm{a}$ & $11.37 \mathrm{a}$ & $78.33 \mathrm{a}$ & 43.03 \\
\hline $\mathrm{T}_{5}[\mathrm{FP}]$ & $72.40 \mathrm{a}$ & $7.67 \mathrm{a}$ & $11.07 \mathrm{a}$ & $72.67 \mathrm{ab}$ & 40.93 \\
\hline $\mathrm{SE}( \pm)$ & 1.067 & 0.567 & 0.586 & 3.444 & 2.083 \\
\hline $\mathrm{CV}(\%)$ & 3.74 & 15.13 & 9.22 & 7.58 & 8.63 \\
\hline $\mathrm{P}$ Value & 0.0001 & 0.004 & 0.003 & 0.030 & 0.321 \\
\hline
\end{tabular}

The figure(s) having common letter(s) in a column do not differ significantly at $5 \%$ level of significance, STB $=$ Soil Test Basis, $\mathrm{CF}=$ Chemical fertilizer, $\mathrm{OM}=$ Organic manure, $\mathrm{CD}=$ Cow dung, $\mathrm{PM}=$ Poultry manure, $\mathrm{COM}=$ Compost, $\mathrm{FP}=$ Farmers' practice, HYG $=$ High yield goal, CV $(\%)=$ Coefficient of variation, $\mathrm{SE}( \pm)=$ Standard error of means, $\mathrm{P}=$ Probability

\section{Grain yield}

The integrated use of cow dung, poultry manure, compost and fertilizers showed a positive effect on grain yield of wheat (Table 3). The grain yield ranged from 2094 to $3554 \mathrm{~kg} \mathrm{ha}^{-1}$. The highest grain yield of $3554 \mathrm{~kg} \mathrm{ha}^{-1}$ was observed in $\mathrm{T}_{3}$ [STB -CF (HYG) +PM (3 t/ha)] and the lowest value of 2094 $\mathrm{kg} \mathrm{ha}^{-1}$ was recorded in $\mathrm{T}_{0}$ (Control). The grain yield produced by the treatments $T_{1}, T_{2}, T_{4}$ and $T_{5}$ was $3345,3249,3399$ and $3171 \mathrm{~kg} \mathrm{ha}^{-1}$, respectively. Based on grain yield, the treatments may be ranked in order of $T_{3}>T_{4}>T_{1}>T_{2}>T_{5}>T_{0}$. With same recommended fertilizer doses poultry manure treated plots gave higher grain yield than cow dung and compost treated plots. This might be due to the presence of uric acids in poultry manure that hastens the release of nutrients from poultry manure than compost and cow dung. The increase in grain yield over control ranged from 51.44 to $69.72 \%$ where the highest increase was obtained in $\mathrm{T}_{3}$ and the lowest one was obtained in $\mathrm{T}_{5}$ FP [farmers' practices] as shown in Table 3. These results are in agreement with Islam et al. (2014) who reported that combined application of manures and fertilizers increased the grain and straw yield of wheat. Malika et al. (2015) 
and Liza et al. (2014) also support the findings of the present study.

\section{Straw yield}

The straw yield of wheat also responded significantly due to combined use of manures and fertilizers (Table 3). The yields of straw ranged from 2232 to $3635 \mathrm{~kg} \mathrm{ha}^{-1}$. The maximum straw yield of $3636 \mathrm{~kg}$ $\mathrm{ha}^{-1}$ was found in $\mathrm{T}_{3}$ [STB-CF (HYG) +PM ( $\left.3 \mathrm{t} / \mathrm{ha}\right)$ and the minimum value of $2232 \mathrm{~kg} \mathrm{ha}^{-1}$ was noted in $\mathrm{T}_{0}$ (control). The treatment may be ranked in the order of $\mathrm{T}_{3}>\mathrm{T}_{2}>\mathrm{T}_{4}>\mathrm{T}_{1}>\mathrm{T}_{5}>\mathrm{T}_{0}$ in terms of straw yield. Regarding the percent increase of straw yield, the highest increase $(62.83 \%)$ was noted in $\mathrm{T}_{3}$ and the lowest increase $(41.92 \%)$ was observed in $\mathrm{T}_{5} \mathrm{FP}$ [Farmers' practices] as shown in Table 3.

These findings are well corroborated with that of Malika et al. (2015), Islam et al. (2014), and Akter et al. (2012) who reported that integrated use of manures and fertilizers increased the grain and straw yield of rice and wheat.

Table 3. Effects of manures and fertilizers on the grain and Straw yields of wheat

\begin{tabular}{|l|c|c|c|c|}
\hline \multicolumn{1}{|c|}{ Treatments } & $\begin{array}{c}\text { Grain yield } \\
\text { (kgha }^{-1} \text { ) }\end{array}$ & $\begin{array}{c}\text { \% yield } \\
\text { increase over } \\
\text { control }\end{array}$ & $\begin{array}{c}\text { Straw yield } \\
\text { (kgha }^{-1} \text { ) }\end{array}$ & $\begin{array}{c}\text { \%yield increase } \\
\text { over control }\end{array}$ \\
\hline $\mathrm{T}_{0}[$ control] & $2094 \mathrm{e}$ & - & $2233 \mathrm{e}$ & - \\
\hline $\mathrm{T}_{1}[\mathrm{STB}-\mathrm{CF}(\mathrm{HYG})]$ & $3345 \mathrm{~b}$ & 59.71 & $3444 \mathrm{c}$ & 54.26 \\
\hline $\mathrm{T}_{2}[\mathrm{STB}-\mathrm{CF}(\mathrm{HYG})+\mathrm{CD}]$ & $3249 \mathrm{c}$ & 55.13 & $3419 \mathrm{c}$ & 53.12 \\
\hline $\mathrm{T}_{3}[\mathrm{STB}-\mathrm{CF}(\mathrm{HYG})+\mathrm{PM}]$ & $3555 \mathrm{a}$ & 69.72 & $3636 \mathrm{a}$ & 62.83 \\
\hline $\mathrm{T}_{4}[\mathrm{STB}-\mathrm{CF}(\mathrm{HYG}) \mathrm{COM}]$ & $3399 \mathrm{~b}$ & 62.29 & $3596 \mathrm{~b}$ & 61.07 \\
\hline $\mathrm{T}_{5}[\mathrm{FP}]$ & $3172 \mathrm{~d}$ & 51.44 & $3169 \mathrm{~d}$ & 41.92 \\
\hline $\mathrm{SE}( \pm)$ & 18.22 & - & 11.74 & - \\
\hline $\mathrm{CV}(\%)$ & 1.01 & - & 0.63 & - \\
\hline $\mathrm{P}$ Value & 0.000 & - & 0.000 & - \\
\hline
\end{tabular}

The figure(s) having common letter(s) in a column do not differ significantly at $5 \%$ level of significance

\section{Nitrogen uptake by wheat}

The results presented in the Table 4 indicate that the $\mathrm{N}$ uptake by wheat grain and straw differed significantly due to the application of manures and fertilizers. Nitrogen uptake by wheat grain ranged from 31.85 to $71.86 \mathrm{~kg} \mathrm{ha}^{-1}$. The maximum $\mathrm{N}$ uptake of $71.86 \mathrm{~kg} \mathrm{ha}^{-1}$ by wheat grain was observed in the

Table 4. Effects of manures and fertilizers on nitrogen treatment $\mathrm{T}_{3}$ [STB-CF (HYG) + PM (3 t/ha)] which was statistically similar with $\mathrm{T}_{1}, \mathrm{~T}_{4}$ and $\mathrm{T}_{5}$ treatments. The minimum $\mathrm{N}$ uptake of $31.85 \mathrm{~kg}$ $\mathrm{ha}^{-1}$ was observed in the control (To). In case of wheat straw, $\mathrm{N}$ uptake ranged from 21.97 to 46.05 $\mathrm{kg} \mathrm{ha}^{-1}$.

\begin{tabular}{|l|c|c|c|}
\hline \multirow{2}{*}{ Treatments } & \multicolumn{3}{c|}{ Nitrogen uptake (kg ha ${ }^{-1)}$} \\
\cline { 2 - 4 } & Grain & Straw & Total \\
\hline $\mathrm{T}_{0}[$ Control] & $31.85 \mathrm{c}$ & $21.97 \mathrm{~b}$ & $53.82 \mathrm{~b}$ \\
\hline $\mathrm{T}_{1}[\mathrm{STB}-\mathrm{CF}(\mathrm{HYG})]$ & $71.34 \mathrm{a}$ & $41.31 \mathrm{a}$ & $112.45 \mathrm{a}$ \\
\hline $\mathrm{T}_{2}[\mathrm{STB}-\mathrm{CF}(\mathrm{HYG})+\mathrm{CD}]$ & $56.86 \mathrm{~b}$ & $40.83 \mathrm{a}$ & $97.69 \mathrm{a}$ \\
\hline $\mathrm{T}_{3}[\mathrm{STB}-\mathrm{CF}(\mathrm{HYG})+\mathrm{PM}]$ & $71.86 \mathrm{a}$ & $46.05 \mathrm{a}$ & $117.90 \mathrm{a}$ \\
\hline $\mathrm{T}_{4}[\mathrm{STB}-\mathrm{CF}(\mathrm{HYG}) \mathrm{COM}]$ & $69.57 \mathrm{a}$ & $39.55 \mathrm{a}$ & $109.11 \mathrm{a}$ \\
\hline $\mathrm{T}_{5}[\mathrm{FP}]$ & $63.95 \mathrm{ab}$ & $39.08 \mathrm{a}$ & $103.04 \mathrm{a}$ \\
\hline $\mathrm{SE}( \pm)$ & 3.85 & 3.32 & 5.96 \\
\hline $\mathrm{CV}(\%)$ & 10.96 & 15.06 & 10.41 \\
\hline $\mathrm{P}$ Value & 0.0002 & 0.007 & 0.0002 \\
\hline
\end{tabular}

The figure(s) having common letter(s) in a column do not differ significantly at $5 \%$ level of significance 
The maximum $\mathrm{N}$ uptake of $46.05 \mathrm{~kg} \mathrm{ha}^{-\mathrm{I}}$ by straw was obtained in the treatment $T_{3}$ which was identical with $\mathrm{T}_{1}, \mathrm{~T}_{2}, \mathrm{~T}_{4}$ and $\mathrm{T}_{5}$. The minimum $\mathrm{N}$ uptake by wheat straw $21.97 \mathrm{~kg} \mathrm{ha}^{-1}$ was recorded in the treatment $\mathrm{T}_{0}$. Total $\mathrm{N}$ uptake by wheat ranged from 53.82 to $117.90 \mathrm{~kg} \mathrm{ha}^{-1}$. The maximum total $\mathrm{N}$ uptake of $117.90 \mathrm{~kg} \mathrm{ha}^{-1}$ was observed in $\mathrm{T}_{3}$ which was statistically similar with the value obtained in $\mathrm{T}_{1}, \mathrm{~T}_{2}, \mathrm{~T}_{4}$ and $\mathrm{T}_{5}$ treatments. The minimum total $\mathrm{N}$ uptake of $53.82 \mathrm{~kg} \mathrm{ha}^{-1}$ was observed in the control treatment. These results support the findings of Islam et al. (2014), Akter et al. (2012) and Parvez et al. (2008) who also observed an increase in $\mathrm{N}$ uptake by wheat and rice through combined application of manures and fertilizers.

\section{Conclusion}

The overall results indicate that the yield of wheat varied considerably among the treatments $T_{1}, T_{2}, T_{3}$ and $T_{4}$ although they received the same amount of nutrients but the sources of nutrients were different. Poultry manure in combination with chemical fertilizers $\left(\mathrm{T}_{3}\right)$ produced the highest grain and straw yield of wheat and it took superior position in all other parameters studied including yield components, N content and uptake. Therefore, it can be concluded that poultry manure in combination with chemical fertilizers can be used successfully in an integrated way using IPNS system for the successful cultivation of wheat.

\section{References}

Akter S, Islam MR, Rahman MM, Hoque MM (2012). Influences of nitrogen supplied from inorganic and organic sources on the yield, nutrient uptake and nitrogen use efficiency of BRRI dhan29. Bangladesh J. Crop Sci. 22-23: 151-158.

BBS (Bangladesh Bureau of Statistics) (2011). Statistical Year Book of Bangladesh. Statistical Division, Ministry of Planning, Govt. People's Republic Bangladesh.
Bremner JM, Mulvaney CS (1982). Nitrogen- total, In Methods of Soil Analysis Part 2, Page AL, Miller RH, Keeney DR (Editors): American Society of Agronomy, Inc, Publisher, Madison, Wisconsin USA. pp. 595-624.

Gomez KA, Gomez AA (1984). Statistical Procedures for Agricultural Research. John Wilely and Sons. New York.

Indira C (2006). Effects of different nitrogen levels on growth, yield and nutrient uptake of wheat (TriticumaestivumL.). Int. J. Agric. Sci. 2: 372374.

Islam MR, Shaikh MS, Siddique AB, Sumon MH (2014). Yield and nutrient uptake by wheat as influenced by integrated use of manures and fertilizers. J. Bangladesh Agril. Univ. 12(1): 7378.

Khan MU, Qasim M, Khan IU (2007). Effect of integrated nutrient management on crop yields in rice-wheat cropping system. Sarhad J.f Agric. 23 (4): 1019-1025.

Liza MMJ, Islam MR, Jahiruddin M, Hasan MM, Alam MA, Shamsuzzaman SM, Samsuri AW (2014). Residual effects of organic manures with different levels of chemical fertilizers on rice. Life Sci. J. 11(12): 6-12.

Malika M, Islam MR, Karim MR, Huda A, Jahiruddin M (2015). Organic and inorganic fertilizers influence the nutrient use efficiency and yield of a rice variety BINA dhan7. Academic Res. J. Agril. Sci. Res. 3(7): 192-200.

Parvez MS, Islam MR, Begum MS, Rahman MS, Abedin Mian MJ (2008). Integrated use of manures and fertilizers for maximizing the yield of BRRI Dhan 30. J. Bangladesh Soc. Agric. Sci. Technol. 5(1 \& 2): 257-260.

Peterson RF (1965). Wheat Interscience Publications. Inc. New York. p. 38

Razzaque MA, Sufain MA, Bodruddin M (1992). Wheat in the national economy of Bangladesh. Proceedings of the first Biennal Conference of the CSSB held during 18-20 January, 1992. pp 13-24.

Satyanarayana V, Prasad PVV, Murthy VRK, Bodty KJ (2002). Influence of integrated use of inorganic fertilizers on yield components of irrigated low land rice. J. Plant Nutri. 87(1-3): 90-93.

Singh R, Singh S, Prasad K (2001). Effect of fertilizer, FYM and row spacing on transplanted rice. Crop Res. 22(2): 296-99. 